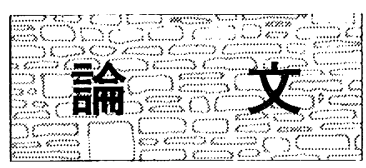

\title{
野外トレーサ試験による堆積岩の分散係数と 有効間隙率の測定
}

\author{
井伊博行 ${ }^{*}$. 石川 泰**. 杉原弘造 $* * *$. 櫨田吉造 $* * * *$

\section{Dispersion coefficient and effective porosity of a sedimentary rock by a field tracer test}

\author{
Ii Hiroyuki*', Ishikawa Yasushi**
Sugihara Kozo $* * *$, Utsugida Yoshizo $* * *$
}

\begin{abstract}
This paper presents the numerical analysis results of a field tracer test. The objective of this test was to measure the dispersivity and the effective porosity of a permeable sedimentary layer. The tracer test was performed using two vertical bore holes 90 meters in depth and located 7 meters apart. The sedimentary layer, composed of sandstone, conglomerate, and weathered granite, was 10 meters thick and started 80 meters below the surface. One bore hole was used to inject groundwater with tracer and the other to recover to recirculate groundwater. We used a tracer solution containing $\mathrm{Br}^{-}$. Before the tracer was injected, groundwater was circulated through the sedimentary layer between the two bore holes to establish a steady state of groundwater flow. The circulation flow rate and $\mathrm{Br}^{-}$concentration initially injected were determined by using Gelhar's analytical solution so that the detectable tracer concentration (several ppm) could be recovered within one month. When the groundwater level at the recovery hole became stable, the tracer was injected into the injection hole and the concentration of $\mathrm{Br}^{-}$was analyzed at the recovery hole. The circulation flow rate was $7800 \mathrm{~cm}^{3} / \mathrm{min}$. The initially injected $\mathrm{Br}^{-}$tracer concentration was $8300 \mathrm{ppm}$. Thirty eight hours later, the concentration of $\mathrm{Br}^{-}$at the recovery hole reached a maximum level of $10 \mathrm{ppm}$.

The convection-dispersion equation was used for the tracer test's numerical analysis. This differential equation was transformed by F. E. M. Half of the horizontal section of the analytical region was used for numerical analysis and meshes like a semi-circle were used for the circulation-line above

* 清水建設(株)技術研究所 Research Institute, Shimizu Corporation

** 動力炉 · 核然料開発事業団 中部事業所 Chubu Works, Power Reactor \& Nuclear Fuel Development Corporation 現在同和工営(株)、Dowa Engineering

*** 動力炉 · 核燃料開発事業団 中部事業所 Chubu Works, Power Reactor \& Nuclear Fuel Development Corporation

****清水建設(株) 原子力本部 Nuclear Power Division, Shimizu Corporation
\end{abstract}


the surface between the two bore holes. A dispersion coefficient depends upon flow velocity, dispersivity, and diffusion. Initially, the flow velocity distribution and the permeability of layer were analyzed using F. E. M. as a seepage problem. The analyzed permeability of the layer was $2.2 \times 10^{-5} \mathrm{~cm} / \mathrm{sec}$.

According to the F. E. M. analysis result, using the breakthrough curve of $\mathrm{Br}^{-}$at the recovery hole and the matching technique, the effective porosity was determined to be $7 \%$ and the dispersivity 3.5 meters. The effective porosity was determined to be $4.5 \%$ and the dispersivity 3.5 meters by Gelhar's analytical solution. The $7 \%$ or $4.5 \%$ effective porosity value was smaller than the $30 \%$ porosity value with the boring core samples. This suggests that the measurement of effective porosity using a field tracer test is important in evaluating groundwater flow velocity and mass transport. The relationship between the dispersivity 3.5 meters and the distance 7 meters agreed well with those of Leonhart (1985).

key words: Tracer, Field test, Effective porosity, Dispersivity, Finite element method, Groundwater flow, Mass transport, Injection hole, Recovery hole トレーサ、野外試験、有効間隙率、分散長、有限要素法、地下水流動、物質移行、注入 孔、揚水孔

\section{1. はじめに}

地層中の地下水の実流速分布を知ることは、様々 の分野で重要である。地層中の地下水の実流速分布 は、地層の有効間陌率、透水係数、地下水位によっ て変化するが、これらの值が判れば解析によって推 定することができる。トレーサ試験は実流速を直接 得る方法のひとつである (Freeze and Cherry, 1979)。Leonhart(1985) は野外での 2 つのボーリン グ孔を用いたトレーサ試験を行い、玄武岩溶岩の分 散係数を Gelhar (Gelhar, 1982)によって導かれた二 次元の解析解で求めると同時に、これまでの野外で のトレーサ試験によって得られた岩石の分散係数に ついてまとめている。このように分散係数について のデー夕は蓄積されつつある。しかし、実流速を求 める上で重要な有効間隙率に関してのデー夕は少な い。そこで、本研究では、2本のボーリング孔を用 いて堆積岩の有効間隙率と分散保数を野外トレーサ 試験により同時に測定し、求められた有効間隙率は ボーリングコアを用いて測定された間隙率と比較 し、また、分散係数はLeonhart(1985)の結果と比 較した。解析には二次元の有限要素法(FEM) によ る解析と Gelhar (Gelhar, 1982)による二次元の解析 解を併用した。なお、トレーサ試験実施前に、 Gelhar (Gelhar, 1982)による二次元の解析解を用い ることによって、揚水量、トレーサの投入量等の試
験条件を設定した。

\section{2. 地形・地質概要}

トレーサ試験場は岐阜県東濃地方で、図一 1 に示 すように試験場付近の地表環境は、左右を山に挟ま れた谷間の小規模な平坦地で、概ね北から南へ流れ ている川が、試験場を迂回している。

この地域は地表面下 $85 \mathrm{~m}$ まで新第三紀の堆積岩が 見られ、その下位に基盤の花崗岩が分布する。図一 2 拈よび 3 に示すように、揚水孔、注入孔の間では、 地層の水平方向の変化は少なく、地表面下約80 $90 \mathrm{~m}$ では基盤の花崗岩の風化部と堆積岩下部のれき 岩・砂岩層等の粗粒堆積物が卓越しており、下位に 基盤の花崗岩、上位に難透水性の砂岩・シルト岩層 が分布することから、この付近が透水ゾーンを形成 しているものと考え、トレーサ試験の区間とした。

図一 2 の揚水孔の深度78 88m までの範囲におけ るボーリングコア10サンプルについて重量法によっ て求めた間隙率と室内での透水試験結果を表一 1 に 示す。堆積岩における間隙率は $30 \%$ 前後で、一部に $5 \%$ 前後の低い值が見られるが、それは花崗岩とそ の砅と考えられる。透水係数は、 $3 \times 10^{-8} \sim 3 \times$ $10^{-6} \mathrm{~cm} / \mathrm{sec}$ で、マサ化した花崗岩では大きな值を 示す。 


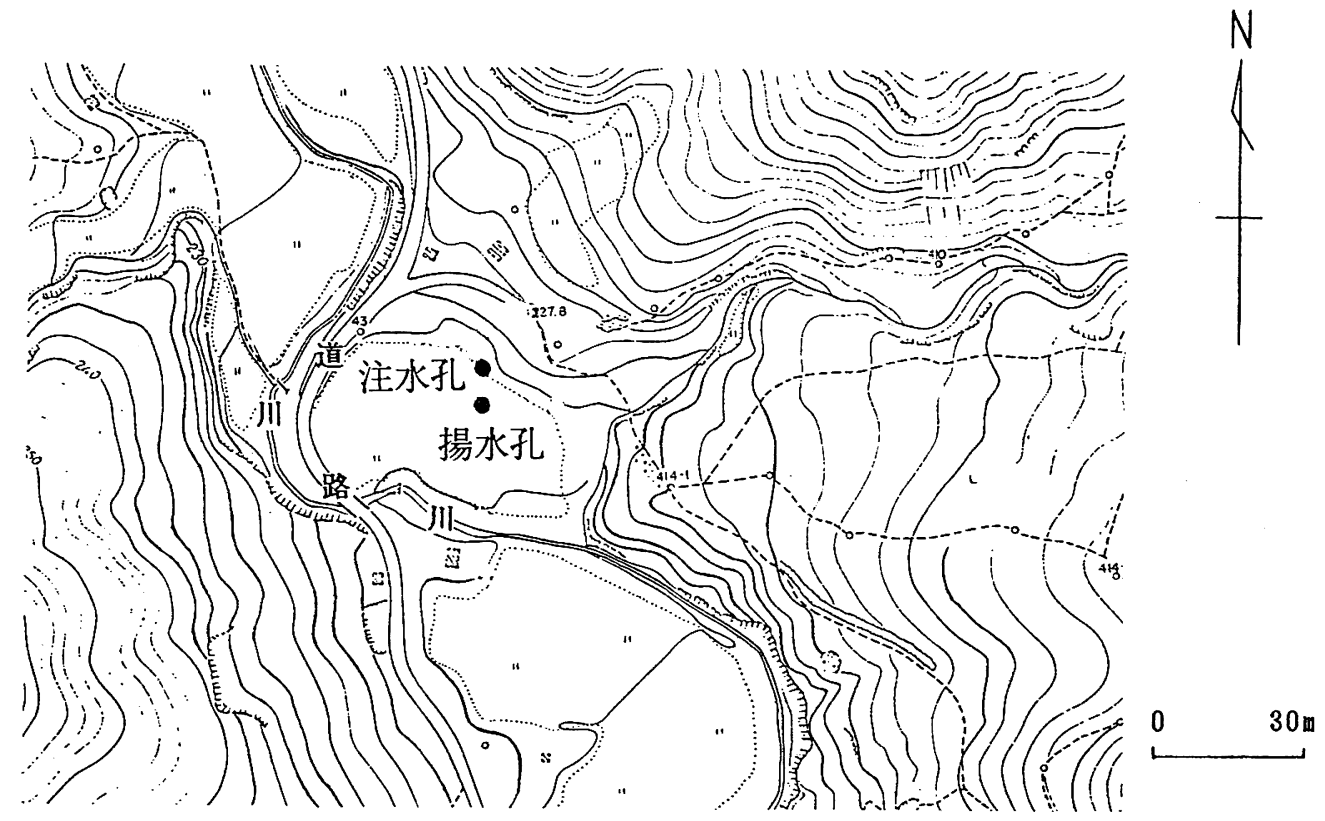

図ー1 トレーサー試験場 (図中○はボーリング孔)

地表面下

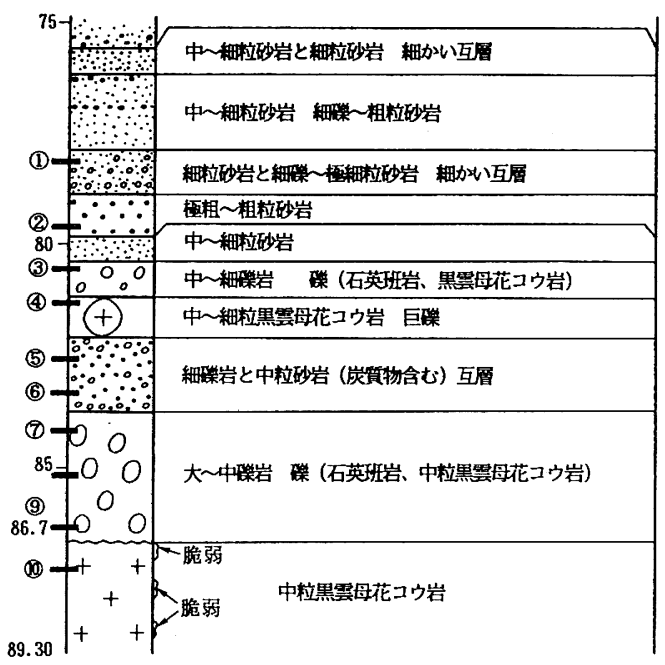

图一２Ａ1－1孔(揚水孔)の地質柱状図

(1) (10)物性試験用サンプル採取位置
地表面下

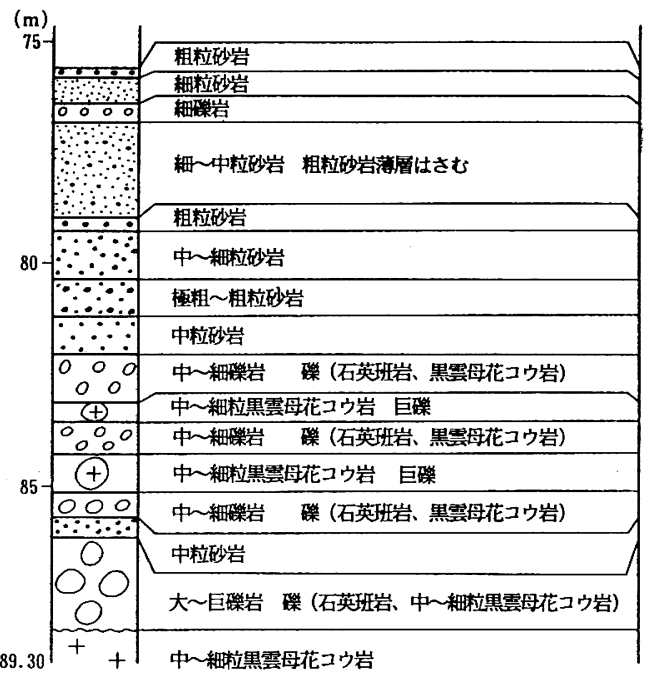

図一3 A1-2孔(注入孔)の地質柱状図 
表ー 1 揚水孔のボーリングコア物性試験

\begin{tabular}{|c|c|c|c|c|}
\hline No & 採取樑度 (M) & 間㗂率 (\%) & 透水係数 $(\mathrm{cm} / \mathrm{sec})$ & 岩石名 \\
\hline 1 & $78.10 \sim 78.20$ & 24.8 & $2.6 \times 10^{-7}$ & 砂岩と細喽岩 \\
\hline 2 & $79.55 \sim 79.65$ & 27.9 & $2.4 \times 10^{-7}$ & 砂岩 \\
\hline 3 & $80.45 \sim 80.55$ & 27.3 & $9.4 \times 10^{-8}$ & 中〜細喽岩 \\
\hline 4 & $81.20 \sim 81.30$ & 26.8 & $1.2 \times 10^{-7}$ & 巨喽岩 \\
\hline 5 & $82.70 \sim 82.80$ & 31.1 & $3.7 \times 10^{-8}$ & 砂岩と細磷岩 \\
\hline 6 & $83.30 \sim 83.40$ & 27.6 & ----- & 砂岩と細喽岩 \\
\hline 7 & $84.10 \sim 84.20$ & 5.5 & $2.7 \times 10^{-8}$ & 大〜中喽岩 \\
\hline 8 & $85.00 \sim 85.10$ & 47.3 & ----- & 大〜中磞岩 \\
\hline 9 & $86.30 \sim 86.40$ & 30.8 & ----- & 大〜中碟岩 \\
\hline 10 & $87.20 \sim 87.30$ & 5.8 & $2.9 \times 10^{-8}$ & 花コウ岩 (マサ化) \\
\hline
\end{tabular}

\section{3. 予測解析}

トレーサ試験を行う前に、解析の容易な Gelhar (Gelhar, 1982)による解析解(解析領域内に揚水孔と 注入孔の 2 孔が存在し、揚水孔から汲み上げた地下 水を注入孔に注水する方法で循環しながら、かつ注 入孔からトレーサを入れた時の揚水孔でのトレーサ 濃度変化を求める水平二次元の解析解) 用いて、 試験条件を設定するための解析を行った。これは水 平二次元での均質媒体中に、トレーサを瞬間的(パ ルス)に注入した場合の解析解であり、分散は流線 方向のみ考慮されている。野外に扔けるトレーサ試 験では繰返して試験を行うことや長期間試験を続け ることが困難である。そのため、予測解析ではトレー サの揚水孔への到達時間を所定の期間(ここでは 1 ケ月)以内になるように、かつ使用トレーサ $\left(\mathrm{Br}^{-}\right)$の ピーク濃度がトレーサの検出限界を十分超えるぐら いになるように、トレーサ投入量、注入・揚水量等 の試験条件を設定する必要がある。ここでは表一 2 に示すように、有効間隙率をボーリングコアの間隙 率を考虑して、最大 $30 \%$ まで想定し、分散長を孔間
表ー2 二次元の解析解による解析条件

\begin{tabular}{|c|c|}
\hline 孔間距離 & $7.0 \mathrm{~m}$ \\
\hline 注水量・掦水量 & $2000 、 4000 、 8000$ or $7800 \mathrm{~cm}^{3} / \mathrm{min}$ \\
\hline 透水首の厚さ & 10m \\
\hline トレーサ量 $(\mathrm{NaBr})$ & 1 or $1920 \mathrm{~g}$ \\
\hline 有効間隙率 & 最大 $30 \%$ \\
\hline 分散長 & $0.07 \sim 7.0 \mathrm{~m}$ \\
\hline
\end{tabular}

距離の0.01から0.2倍とし、流量をポンプの性能か ら最大 $8000 \mathrm{~cm}^{3} / \mathrm{min}$ まで検討した。その予測解析 結果を表一 3 に示す。この結果から、ピーク濃度が 最小でも十分トレーサが検出可能となるように、注 入・揚水量を $8000 \mathrm{~cm}^{3} / \mathrm{min}$ 、トレーサ投入量を $\mathrm{NaBr}$ で $2000 \mathrm{~g}(0.0014 \times 2000 \times 79.9 / 102.9=$ $2.2 \mathrm{ppm})$ とした。

なお、Gelharの解析解は以下のように示される。 
表ー 3 トレーサ量が $1 \mathrm{~g}$ の時の揚水孔におけるトレーサのピーク濃度と到達時間

\begin{tabular}{|c|c|c|c|c|c|c|c|}
\hline \multicolumn{2}{|c|}{ 注入・揚水量 } & \multicolumn{2}{|c|}{$2000 \mathrm{~cm}^{3} / \mathrm{min}$} & \multicolumn{2}{|c|}{$4000 \mathrm{~cm}^{3} / \mathrm{min}$} & \multicolumn{2}{|c|}{$8000 \mathrm{~cm}^{3} / \mathrm{min}$} \\
\hline $\begin{array}{c}\text { 分散長 } \\
(\text { (u) }\end{array}$ & $\begin{array}{c}\text { 有効間隙 } \\
\text { 率(\%) }\end{array}$ & $\begin{array}{c}\text { 到達時間 } \\
\text { (day) }\end{array}$ & $\begin{array}{l}\text { 濃度 } \\
(\mathrm{ppm})\end{array}$ & $\begin{array}{c}\text { 到達時間 } \\
(\mathrm{day})\end{array}$ & $\begin{array}{l}\text { 濃度 } \\
(\mathrm{ppm})\end{array}$ & $\begin{array}{c}\text { 到達時間 } \\
\text { (day) }\end{array}$ & $\begin{array}{l}\text { 懐度 } \\
(\mathrm{ppm})\end{array}$ \\
\hline 1.4 & $\begin{array}{r}30 \\
10 \\
5\end{array}$ & $\begin{array}{l}95.9 \\
32.0 \\
16.0\end{array}$ & $\begin{array}{l}0.0014 \\
0.0042 \\
0.0084\end{array}$ & $\begin{array}{r}47.9 \\
16.0 \\
8.0\end{array}$ & $\begin{array}{l}0.0014 \\
0.0042 \\
0.0084\end{array}$ & $\begin{array}{r}24.0 \\
8.0 \\
4.0\end{array}$ & $\begin{array}{l}0.0014 \\
0.0042 \\
0.0084\end{array}$ \\
\hline 0.7 & $\begin{array}{r}30 \\
10 \\
5\end{array}$ & $\begin{array}{l}66.4 \\
22.1 \\
11.1\end{array}$ & $\begin{array}{l}0.0018 \\
0.0054 \\
0.0108\end{array}$ & $\begin{array}{r}33.2 \\
11.1 \\
5.5\end{array}$ & $\begin{array}{l}0.0018 \\
0.0054 \\
0.0108\end{array}$ & $\begin{array}{r}16.6 \\
5.5 \\
2.8\end{array}$ & $\begin{array}{l}0.0018 \\
0.0054 \\
0.0108\end{array}$ \\
\hline 0.07 & $\begin{array}{r}30 \\
10 \\
5\end{array}$ & $\begin{array}{r}58.7 \\
19.6 \\
9.8\end{array}$ & $\begin{array}{l}0.0038 \\
0.0114 \\
0.0228\end{array}$ & $\begin{array}{r}29.4 \\
9.8 \\
4.9\end{array}$ & $\begin{array}{l}0.0038 \\
0.0114 \\
0.0228\end{array}$ & $\begin{array}{r}14.7 \\
4.9 \\
2.4\end{array}$ & $\begin{array}{l}0.0038 \\
0.0114 \\
0.0228\end{array}$ \\
\hline
\end{tabular}

$$
\begin{aligned}
& \mathrm{C}_{\mathrm{w}}=\frac{\mathrm{Q}}{\mathrm{M}} \int_{\hat{\varphi}=0}^{1} \frac{\mathrm{Qexp}\left[-(\mathrm{a}-\mathrm{T})^{2} / 4 \mathrm{eb}\right]}{\varepsilon \mathrm{hL}^{2}(4 \pi \mathrm{eb})^{\frac{1}{2}}} \mathrm{~d} \hat{\varphi} \\
& \mathrm{T}=\frac{\mathrm{Qt}}{\varepsilon \mathrm{hL}^{2}} \quad \mathrm{e}=\frac{\alpha}{\mathrm{L}}
\end{aligned}
$$$$
\mathrm{a}(\varphi)=\pi(\sin \phi-\phi \cos \phi) / \sin ^{3} \phi \quad: \phi=\pi \varphi
$$$$
\mathrm{b}(\gamma, \phi)=\pi^{2}[(\gamma+\phi) / 2+(\sin \gamma \cos \gamma) / 2
$$$$
+(\sin \phi \cos \phi) / 2
$$$$
-2 \cos \phi(\sin \gamma+\sin \phi)
$$$$
\left.+(\gamma+\phi) \cos ^{2} \phi\right] / 2 \sin ^{5} \phi
$$

$$
\begin{aligned}
\mathrm{C}_{\mathrm{w}} \text { : 揚水孔での濃度 } & \varepsilon: \text { : 有効間隙率 } \\
\mathrm{Q}: \text { 注入・揚水量 } & \mathrm{h} \text { : 層厚 } \\
\mathrm{M}: \text { トレーサー量 } & \gamma: \text { 時間 } \mathrm{t} \text { におけるパ } \\
& \text { ルスの位置 }
\end{aligned}
$$

\section{$\varphi$ : 流れ関数 $\hat{\varphi}=2 \mathrm{~h} \varphi / \mathrm{Q} \mathrm{L}: 2$ 孔間の距離}

$$
\alpha \text { : 分散長 }
$$

$$
\mathrm{t} \text { : 時間 }
$$

\section{4. トレーサ試験}

\section{1 試験方法}

図ー 4 に示すようにトレーサ試験は $7 \mathrm{~m}$ 離れた 2 本のボーリング孔(孔径 $146 \mathrm{~mm})$ を用い、一方のボー リング孔(注入孔)に注水を行い、他方のボーリング 孔(揚水孔)から揚水を行って、強制的に定常的な循 環する流れを発生させた。その上で、トレーサを注 入孔から短時間に注入し、揚水した地下水中のト レーサ濃度を測定する方式でトレーサ試験を行っ た。試験区間は図－2に示したように周囲よりも透 水性が大きいと考えられる地表面下約80～90m の層 厚 $10 \mathrm{~m}$ の区間である。地表面下 $80 \mathrm{~m}$ の深度までケー シングが設置してあり、そのケーシングより下部の 試験区間の $10 \mathrm{~m}$ は、水の出入りができるようにスト レーナが備えられ、また、上部とはパッカーで縁切 りされている。この注入孔ではパッカーにより加圧 した水の注入が可能であるが、揚水孔はパッカーが 設置されておらず水位は自由に変動する。試験区間 下部は未風化の花崗岩で難透水層と考えている。

試験は、トレーサ注入前(地下水の循環が平衡に なり安定する)、トレーサ注入時(注入孔にトレーサ を注入する)、サンプリング時(揚水孔から地下水を サンプリングする)の 3 つに分けることができる。

\section{1) トレーサ注入前}

図ー 4 に示すように揚水孔の孔底にあるポンプに よって、揚水孔から汲み上げられた地下水を、直接 注入孔に送水した。その時の地上部における流量は $7800 \mathrm{~cm}^{3} / \mathrm{min}$ (設定値は $8000 \mathrm{~cm}^{3} / \mathrm{min}$ )、送水圧は $7.7 \mathrm{~kg} / \mathrm{cm}^{2}$ でほぼ一定となった。

\section{2)トレーサ注入時}

トレーサ水溶液としては、前もって汲み上げた地 下水にトレーサ $(\mathrm{NaBr})$ を溶解させ、 $\mathrm{Br}^{-} を 8300 \mathrm{ppm}$ 含む水溶液を $180000 \mathrm{~cm}^{3}$ 作製 $(\mathrm{NaBr}$ で $1920 \mathrm{~g})$ した。 図ー 5 に示すようにトレーサ注入時は、揚水孔から の水を注入せずに、このトレーサ水溶液のみを注入 した。このため、注入する溶液は揚水孔から送水す る水と混合しないので、一定濃度の溶液を注入する ことが可能となる。また、トレーサの注入量、揚水 孔からの揚水量は、トレーサ注入前の流量 $7800 \mathrm{~cm}^{3}$ / minになるように調節し、注入時間は約 23 分間で 

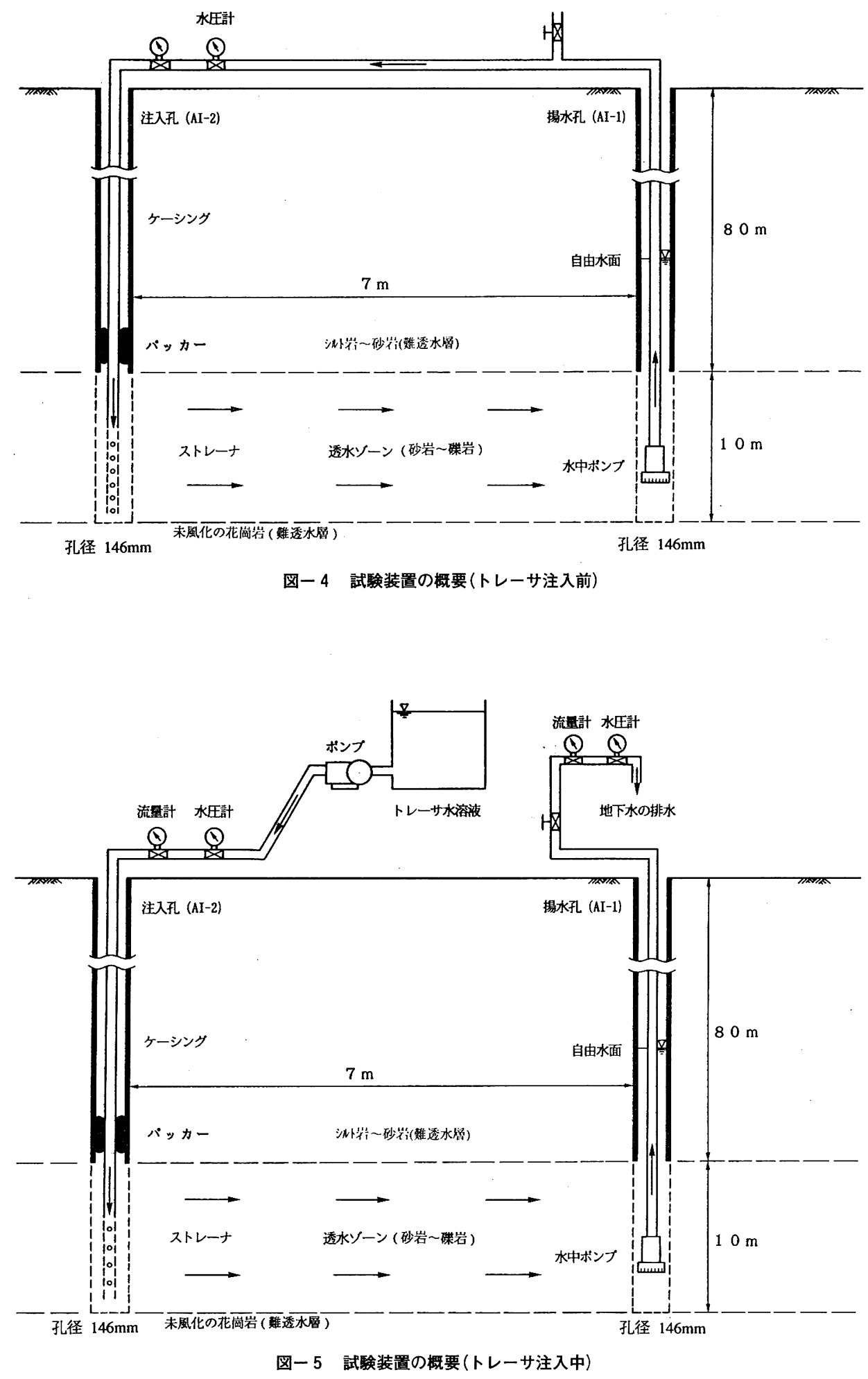
あった。

3 )サンプリング時

図一 6 に示すようにサンプリング時は、トレーサ 注入前と同じように、揚水孔から揚水した地下水を 直接、注入孔に送水した。その時の流量は、トレー サ注入前と同じ $7800 \mathrm{~cm}^{3} / \mathrm{min}$ になるように調節し た。なお、この期間は揚水孔から揚水した地下水の 一部を一定間隔でサンプリングした。地下水中の $\mathrm{Br}$ 濃度の測定はイオンクロマトグラフ法で行った。

\section{2 試験結果}

図ー7にトレーサ注入後に揚水した地下水の $\mathrm{Br}^{-}$ 濃度の経時変化を示す。 $\mathrm{Br}^{-}$濃度のピーク時は注入 から38時間 (2290分)後で、その濃度は約 $10 \mathrm{ppm}$ で あり、予想より早い時期にトレーサが到達し、トレー サの濃度は十分検出できる範囲であった。バックグ ランドとしての $\mathrm{Br}^{-}$は0.002ppm 以下であった。ま た、ピーク時以降の濃度の降下曲線は立上がり時に 比べて非常に緩いが、これは、揚水孔から揚水され た $\mathrm{Br}^{-}$を含む地下水を再び注入孔に注入しているた めと考えられる。

また、図ー8に揚水孔の水位の経時変化を示す。
水位は循環開始後 2 日程で平衡状態に達し、トレー サ注入時はすでに地下水の流れは安定していたもの と考えられる。

循環前の注入孔と揚水孔及び周辺のボーリング孔 の水位は地表面下約 $21 \mathrm{~m}$ で、ほぼ一定で卓越した流 れはなかった。

\section{5. 二次元の有限要素法による解析}

二次元の有限要素法(FEM)による解析では、ま ず、浸透流解析を行い水平二次元場での地下水の流 速分布を計算し、次に、その流速分布を用いて同じ く水平二次元場での物質移行解析を行った。

\section{1 浸透流解析}

1 ) 解析方法

まず、水平二次元場 V での定常浸透流方程式は、 一般に次式のように表される。

$$
\frac{\partial^{2} \phi}{\partial \mathrm{x}^{2}}+\frac{\partial^{2} \phi}{\partial \mathrm{y}^{2}}=0 \quad \text { in } \mathrm{V}
$$

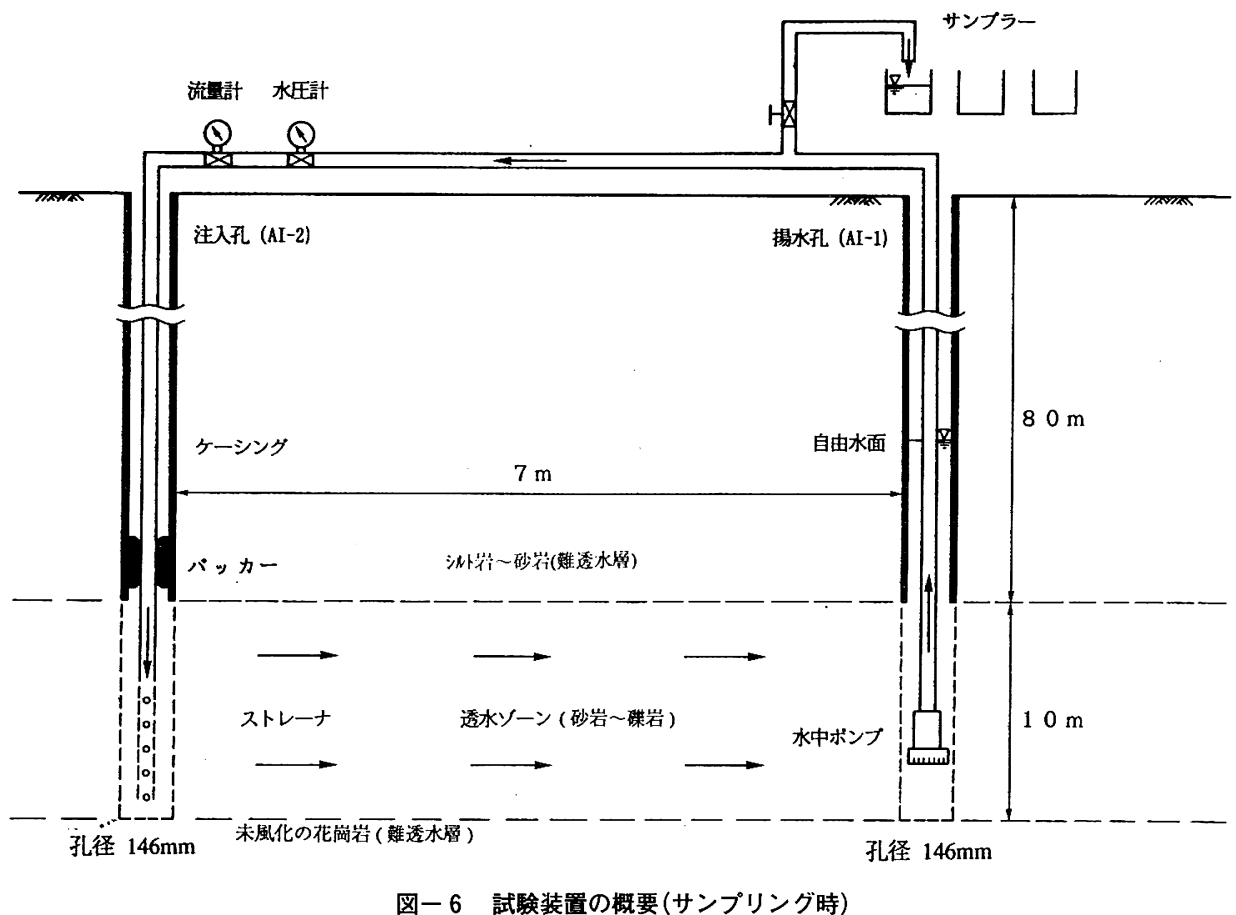




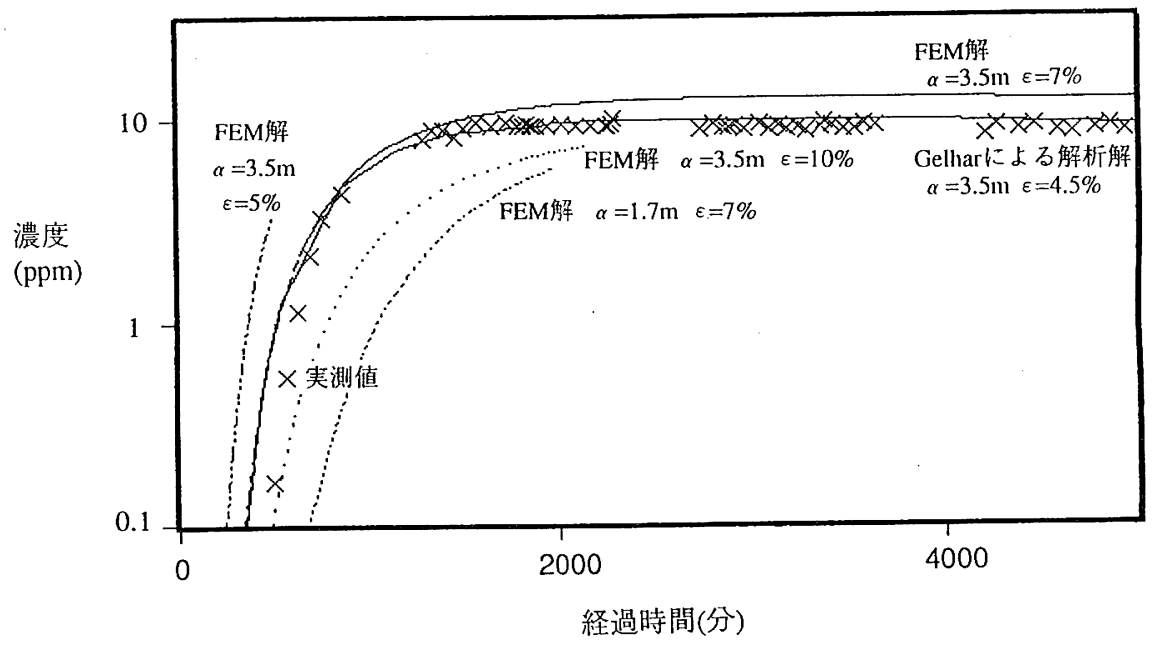

図一 7 揚水孔における実測 $\mathrm{Br}^{-}$蜄度変化と二次元解析結果

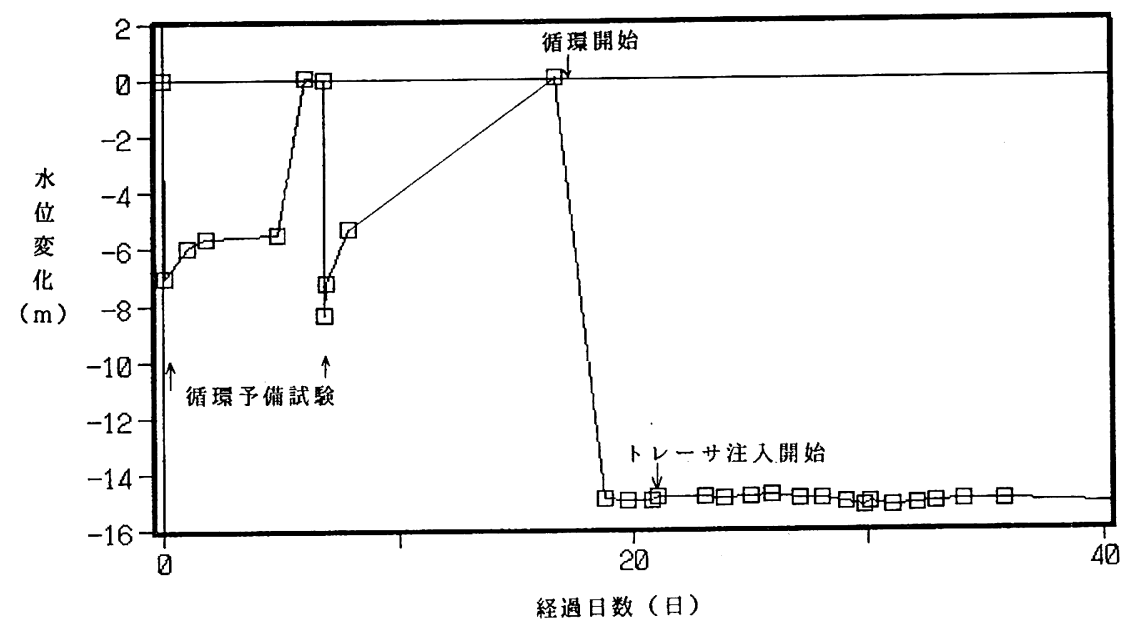

図一8 A1-1孔(揚水孔)の孔内水位変化

一方、境界条件は、水頭固定境界 $\mathrm{S}_{1}$ 及び強制流 量境界 $\mathrm{S}_{2}$ において次のように表される。
$\phi=\phi_{0}$
on $\mathrm{S}_{1}$
$\mathrm{q}=\mathrm{q}_{0}$
on $\mathrm{S}_{2}$
$\phi$ : 全水頭
$\phi_{0}:$ 境界における全水頭
$\mathrm{q}$ : 流量
$\mathrm{q}_{0}$ : 境界における流量
$\mathrm{x}, \mathrm{y}$, : 座標

浸透流解析は( 2 )式と（ 3 )式にFEMを適用して 導いた代数方程式を基にコンピュターを用いて実行 した。

\section{2 )解析条件 \\ 図一 9 に解析モデルを示す。解析領域は注入孔と} 揚水孔を結ぶ線を対称軸とした半分の領域のみを考 えた。また、地下水の循環を表現するため、半円形 の水路(循環路)を設けたが、浸透流解析ではこの部 分は解析領域に含まれていない。この浸透流解析の. 


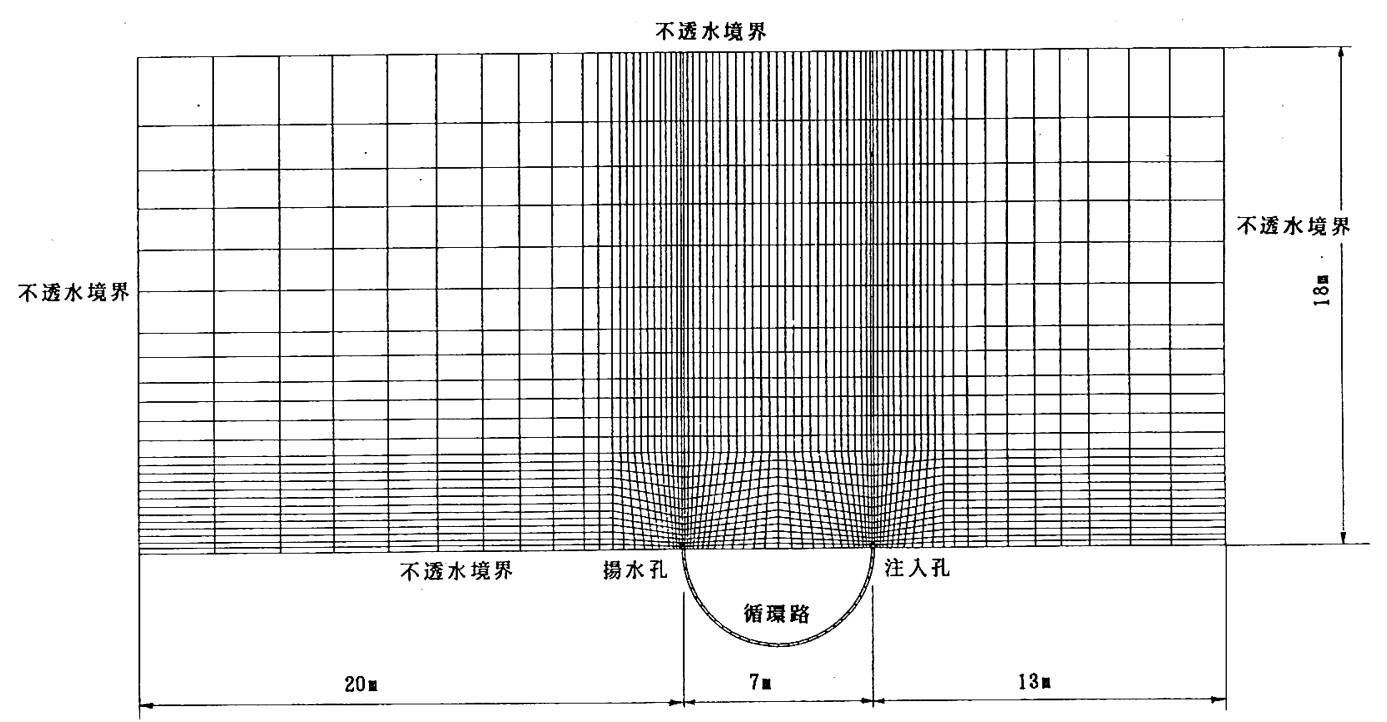

図一9解析モデル(平面図)

解析条件を表一 4 に示す。対象した地層の厚さは $10 \mathrm{~m}$ 、注入孔の注入量は実測值の半分の $3900 \mathrm{~cm}^{3} /$ $\min (1 / 2$ の領域のため)、揚水孔の地下水位は自然 水位 $(\mathrm{GL}-21 \mathrm{~m})$ よりも $15 \mathrm{~m}$ 小さい值を観測結果に基 づき入力した。注入孔の地下水位は地上での注入圧

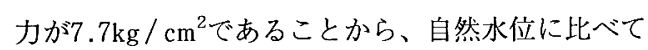
$98 \mathrm{~m}(77+21 \mathrm{~m})$ 上位にあり、解析によって得られる 注入孔の水頭值が試験時の水頭值に一致するように 透水係数を変数として計算した。な拉、地層の透水 係数は、石川・杉原(1991)の水理評価によってこの 付近では $5.0 \times 10^{-6} \sim 1.0 \times 10^{-4} \mathrm{~cm} / \mathrm{sec}$ が求められ ている。これらの条件によって水平二次元場での地 下水のポテンシャル分布(流速分布)を求めた。

\section{3 )解析結果}

解析の結果、図一10のポテンシャル分布を得た。 透水係数が $2.2 \times 10^{-5} \mathrm{~cm} / \mathrm{sec}$ の時に注入孔の水頭值 が試験時の水頭值 $98 \mathrm{~m}$ に一致した。この透水係数は 表一 1 に示すボーリングコアから求められた透水係 数よりも大きい。

\section{2 物質移行解析}

1 ) 解析方法

物質移行解析で用いる水平二次元移流・分散方程 式は、次式のように表される。
表一 4 二次元の浸透流解析の条件

\begin{tabular}{|c|c|}
\hline 首厚 & $10 \mathrm{~m}$ \\
\hline 透水保数 & $5 \times 10^{-6} \sim 1 \times 10^{-4} \mathrm{~cm} / \mathrm{sec}$ \\
\hline 境界条件 & 不透水境界(注入孔、揚水孔を除く) \\
\hline 注入孔 & 流量境界 : $3900 \mathrm{~cm}^{3} / \mathrm{min}(1 / 2$ の領域) \\
\hline 掦水孔 & 水頭境界 : $-15 \mathrm{~m}$ (自然水位と比較して) \\
\hline
\end{tabular}

注：循環路は解析領域に含まれない。

$$
\begin{gathered}
\frac{\partial \mathrm{C}}{\partial \mathrm{t}}=\mathrm{D} \frac{\partial^{2} \mathrm{C}}{\partial \mathrm{x}^{2}}+\mathrm{D} \frac{\partial^{2} \mathrm{C}}{\partial \mathrm{y}^{2}}-\mathrm{Vx} \frac{\partial \mathrm{C}}{\partial \mathrm{x}}-\mathrm{Vy} \frac{\partial \mathrm{C}}{\partial \mathrm{x}} \\
\mathrm{Vx}=\mathrm{vx} / \varepsilon, \mathrm{Vy}=\mathrm{vy} / \varepsilon \\
\text { ここに、 } \begin{array}{r}
\varepsilon \text { : 有効間隙率、 } \mathrm{h} \text { : 層厚、 } \\
\mathrm{C} \text { : 溶液中のトレーサ濃度 } \\
\mathrm{D} \text { : 分散係数、 }
\end{array}
\end{gathered}
$$

$\mathrm{Vx} 、 \mathrm{Vy}: \mathrm{X} 、 \mathrm{Y}$ 方向の実流速

$\mathrm{vx} 、 \mathrm{vy}$ : 浸透流解析から求められた $\mathrm{X} 、 \mathrm{Y}$ 方向のダルシー流速 


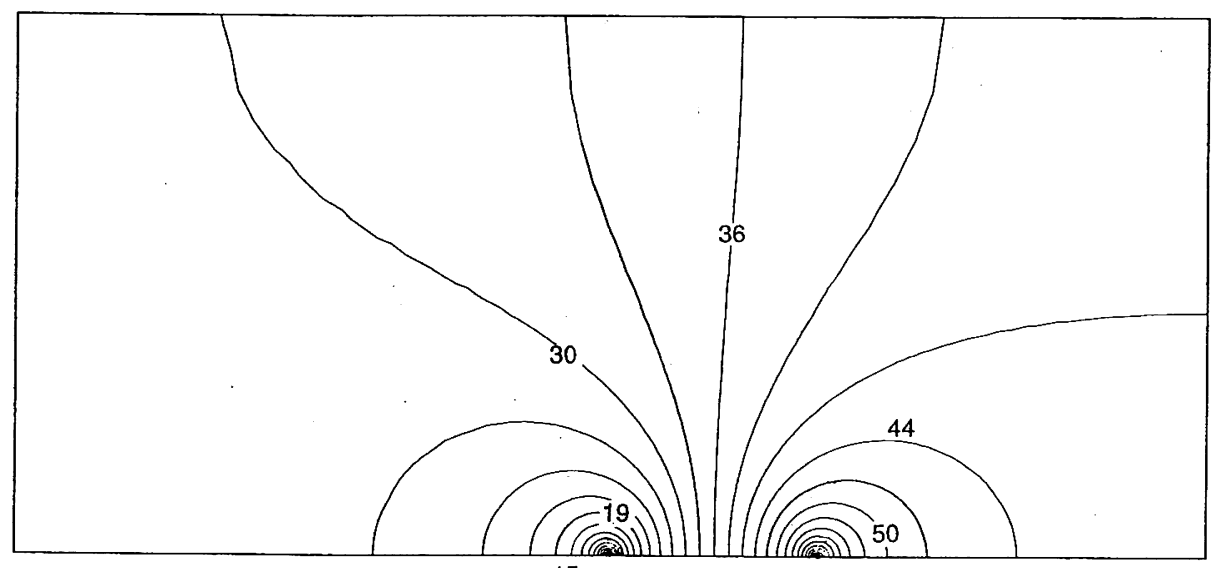

$-15 m$

$98 \mathrm{~m}$

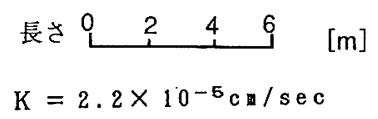

图-10 ポテンシャル分布

ここで、分散係数は流線方向とそれに直交する方 向では、次のように設定される。

$$
\mathrm{D}_{1}=\alpha|\mathrm{V}|+\mathrm{Dm} 、 \quad \mathrm{D}_{2}=\mathrm{Dm}
$$

ここに、 $\mathrm{D}_{1}$ : 流線方向の分散係数、

$\mathrm{D}_{2}$ : 流線と直交する方向の分散係数

$$
\begin{aligned}
& |\mathrm{V}|: \sqrt{\mathrm{Vx}^{2}+\mathrm{Vy}^{2}} 、 \quad \alpha \text { : 分散長 } \\
& \mathrm{Dm} \text { : 分子拡散係数 }
\end{aligned}
$$

また、本来テンソル量である分散係数 Dij と $\mathrm{D}_{1}$ 、 $\mathrm{D}_{2}$ との関係を示すと以下の通りとなる。

$$
\begin{aligned}
& \left(\begin{array}{ll}
\mathrm{D}_{\mathrm{xx}} & \mathrm{D}_{\mathrm{xy}} \\
\mathrm{D}_{\mathrm{yx}} & \mathrm{D}_{\mathrm{yy}}
\end{array}\right)=\left(\begin{array}{cc}
\cos \theta & -\sin \theta \\
\sin \theta & \cos \theta
\end{array}\right)\left(\begin{array}{cc}
\mathrm{D}_{1} & 0 \\
0 & \mathrm{D}_{2}
\end{array}\right)\left(\begin{array}{cc}
\cos \theta & \sin \theta \\
-\sin \theta & \cos \theta
\end{array}\right) \\
& =\left(\begin{array}{cc}
\mathrm{D}_{1} \cos ^{2} \theta+\mathrm{D}_{2} \sin ^{2} \theta & \mathrm{D}_{1} \sin \theta-\mathrm{D}_{2} \sin \theta \cos \theta \\
\mathrm{D}_{1} \sin \theta \cos \theta-\mathrm{D}_{2} \sin \theta \cos \theta & \mathrm{D}_{1} \sin ^{2} \theta+\mathrm{D}_{2} \cos ^{2} \theta
\end{array}\right) \quad(6) \\
& \text { ここで、 } \theta=\arctan (\mathrm{Vy} / \mathrm{Vx}) \text { である。( } 6 \text { )式の }
\end{aligned}
$$
関係を用いて( 4 )式を修正すると流速依存の異方分 散係数を持つ二次元移流・分散方程式が次式のよう に導かれる。

$$
\begin{aligned}
& \frac{\partial C}{\partial t}=D_{x x} \frac{\partial^{2} C}{\partial x^{2}}+D_{x y} \frac{\partial^{2} C}{\partial x \partial y}+D_{y x} \frac{\partial^{2} C}{\partial y \frac{\partial x}{\partial}} \\
& +D_{y y} \frac{\partial^{2} C}{\partial y^{2}}-V_{x} \frac{\partial C}{\partial x}-V_{y} \frac{\partial C}{\partial y} \quad \text { in } V
\end{aligned}
$$

一方、境界条件は、濃度固定境界 $\mathrm{S}_{1}$ および強制 物質流入境界 $\mathrm{S}_{2}$ において次のように表される。

$$
\left.\begin{array}{lll}
\mathrm{C}=\mathrm{C}_{0} & \text { on } & \mathrm{S}_{1} \\
\mathrm{f}=\mathrm{f}_{0} & \text { on } & \mathrm{S}_{2}
\end{array}\right\}
$$

ここに、f：物質流入量

$$
\mathrm{f}_{\mathrm{o}} \text { : 境界における物質流入量 }
$$$$
\mathrm{C}_{0}: \text { 境界における濃度 }
$$

物質移行解析は(7)式と（8)式にFEMを適用し て導いた代数方程式を基にコンピュータを用いて実 行した(櫨田他、1984、櫨田、1986)。

\section{2 )解析条件}

表ー 5 に解析条件を示す。解析モデルは図ー9の 浸透流解析で用いたモデルで循環路は解析領域に含 まれている。循環路での流速は、循環路幅を $10 \mathrm{~cm}$ とすると、注入量から $0.39 \mathrm{~cm} / \mathrm{min}$ と計算され、そ れ以外の流速は浸透流解析の結果を用いた。トレー 
表一 5 二次元の物質移行解析の条件

\begin{tabular}{|c|c|}
\hline 初期搌度(注入孔) & $1700 \mathrm{ppm}(112.8$ 分間) \\
\hline 透水係数 & $2.2 \times 10^{-6} \mathrm{~cm} / \mathrm{sec}$ \\
\hline 流速分布 & 浸透流解析結果を利用 \\
\hline 有効間隙率 & 最大 $30 \%$ \\
\hline 分散長 & $0.014 \sim 7.0 \mathrm{~m}$ \\
\hline 層厚 & $10 \mathrm{~m}$ \\
\hline 境界条件 & 不透水境界 \\
\hline
\end{tabular}

注 : 循環路は解析領域に含まれる。循環路 $($ 幅 $10 \mathrm{~cm}$ ) の流速は、 $3900 \mathrm{~cm}^{3} / \mathrm{min} \div(10 \mathrm{~cm} \times 1000 \mathrm{~cm})$ $=0.39 \mathrm{~cm} / \mathrm{min}=0.0065 \mathrm{~cm} / \mathrm{sec}$

サ試験では $\mathrm{Br}^{-} 8300 \mathrm{ppm}$ の水溶液 $180000 \mathrm{~cm}^{3}$ を注入 量 $7800 \mathrm{~cm}^{3} / \min$ の割合で注入したが、注入前にす でに孔内には循環水 $700000 \mathrm{~cm}^{3}$ が滞留している。注 入孔での濃度の設定方法は、混合の全く起こらない ピストン流モデル、完全混合モデルなどがあるが、 ここでは孔内の濃度変化を構造上把握することがで きなかったので、便宜的に両モデルの中間的でかつ 簡易な方法として、注入したトレーサ量が一致する ようにトレーサ投入濃度が $1700 \mathrm{ppm}\left(180000 \mathrm{~cm}^{3} \times\right.$ $\left.8300 \mathrm{ppm} /(700000+180000) \mathrm{cm}^{3}\right)$ の一定濃度で、 112.8 分間 $\left((700000+180000) \mathrm{cm}^{3} / 7800 \mathrm{~cm}^{3} / \mathrm{min}\right)$ 維 持されたと仮定した。

対象とした地層の層厚は、ストレーナ区間の $10 \mathrm{~m}$ とし、この区間で地層は均質で、透水係数、有効間 隙率は一様であるとした。また、分子拡散係数を 1 $\times 10^{-7} \mathrm{~m}^{2} / \mathrm{h}\left(2.8 \times 10^{-9} \mathrm{~cm}^{2} / \mathrm{sec}\right)$ とした。

\section{3 )解析結果及び考察}

図一7 に揚水孔での実測 Br 濃度と二次元の FEM による解析解およびGelharによる解析解の結果を 示す。表一 2 に示す条件 (注水量・揚水量 :

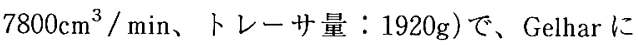
よる二次元の解析解により、0.1ppm から最大濃度 までの範囲で実測值とよく一致したパラメー夕值 は、分散長 $3.5 \mathrm{~m}$ 、有効間隙率 $4.5 \%$ であった。この
值を参考にして二次元の FEMによる解析を行い、 分散長 $3.5 \mathrm{~m}$ 、有効間隙率 $7 \%$ (正確には有効間隙率 7 〜 10\%)を得た。このように両解析によって得ら れた地層の有効間隙率は $7 \%$ と $4.5 \%$ と違い(初期濃 度の設定条件の違いなどが考えられる)があるもの の、重量法によりボーリングコアから得られた間隙 率30\%とは大きく異なっていることが判る。この違 いは本トレーサ試験に扔ける物質移動を考える上 で、有効間隙率を間隙率で代用することができない ことを示している。

トレーサ試験によって得られた地層の有効間隙率 とボーリングコアから得られた間隙率が一致しない 原因は、

1)岩相の違いによる透水性の不均質性があり、選 択的に透水性の大きい岩相の部分を水が流れる ため、全体としての間隙率が小さくなる。

2)亀裂の存在により、1)と同様に選択的な流れが 起こる。

3)ボーリングコアから得られた間隙率が有効間隙 率と一致しないようなミクロなレベルでの選択 的な流れがある(井伊他, 1990a、井伊他, 1990b)。

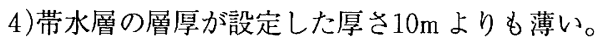
等が考えられる。

1)、2)に関連した帯水層の不均質性については、 石川・杉原(1991)の水理評価によれば、注入孔と揚 水孔近傍の透水係数は、 $2 \times 10^{-5} \mathrm{~cm} / \mathrm{sec}$ でほぼ一 致しており、この 2 孔間では透水性は均質と考えら れる。ただし、FEM の解析領域まで範囲を広げる と透水係数は $5.0 \times 10^{-6} \sim 1.0 \times 10^{-4} \mathrm{~cm} / \mathrm{sec}$ の範囲 で変動し、周辺の影響を重視すると不均質性を考虑 する必要があるものと考えられる。今後は、地層の 不透水性(水みちの存在)をチェックするために揚水 孔と注入孔を入れ換えたトレーサ試験(不可逆性の チェック)や周辺のボーリング孔を用いたトレーサ 試験(透水性の影響)佖必要であると考えられる。

両解析によって得られた分散長は孔間距離の $1 / 2$ の $3.5 \mathrm{~m}$ で一致した。図ー11に示すように、ここで 得られた分散長は Leonhart(1985)が示した堆積岩 の経験的な距離と分散長との関係とも一致してお り、分散長は距離から推定することが可能であると 考えられる。

図－12、13、14、15、16にトレーサ注水2、4、12、 36、100時間後の濃度分布を示す。注入直後の 2 時 
間後では、トレーサは注入孔周辺に同心円状に広 がっていることが判る。その後、トレーサのピーク 濃度の位置は注人孔の周辺に2 2 所見られ、2つの ピークの濃度は時間と共に低下するが、その位置の 動きは小さいこともわかる。

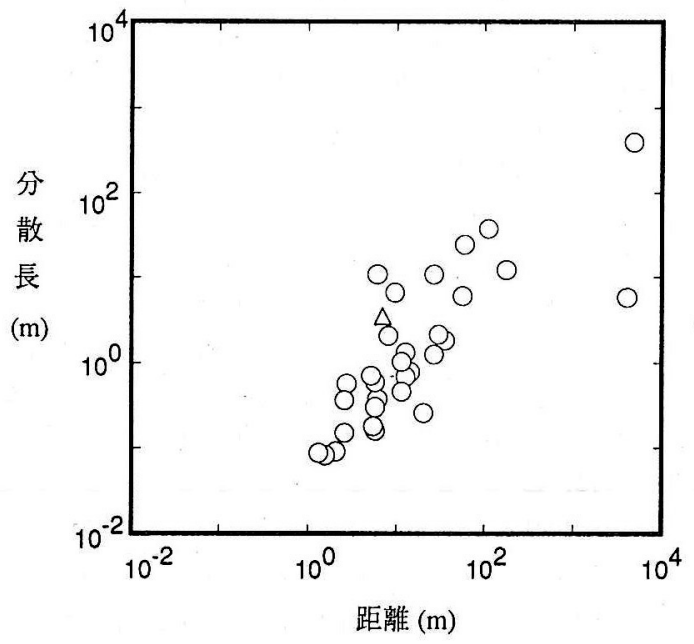

図-11 分散長と距離との関係 $\triangle$ 本測定值 ○堆積岩 (Leonhart, 1985より)

\section{6. まとめ}

野外トレーサ試験により、地層の透水係数、分散 長、有効間隙率を求めた。地層の透水係数は $2.2 \times$ $10^{-5} \mathrm{~cm} / \mathrm{sec}$ でボーリングコアから求められた透水 係数に比べて大きい值であった。有効間隙率につい てはGelharの二次元の解析解 (Gelhar, 1982) およ びFEM解析によって得られた值は、供試体から得 られた值の約 $1 / 4$ 以下となった。このことは、今回 の試験からは物質移行の解析を行う上で有効間隙率 を供試体サイズで測定した間隙率で代用することは できず、有效間隙率を測定することが重要であるこ とを意味している。有効間隙率と間隙率が一致しな い理由は、特定することはできなかったが、選択的 な流れが原因の一つと考えられる。分散長は Leonhart(1985)が示した堆積岩の経験的な距離と分 散長との関係と一致した。

\section{7. 謝辞}

本研究を進めるにあたり、千葉大学理学部地学科 新藤静夫教授、佐倉保夫助教授、清水建設株式会社 技術研究所 大塚義之部長には有益な助言をしてい ただき、謹んで感謝の意を表します。

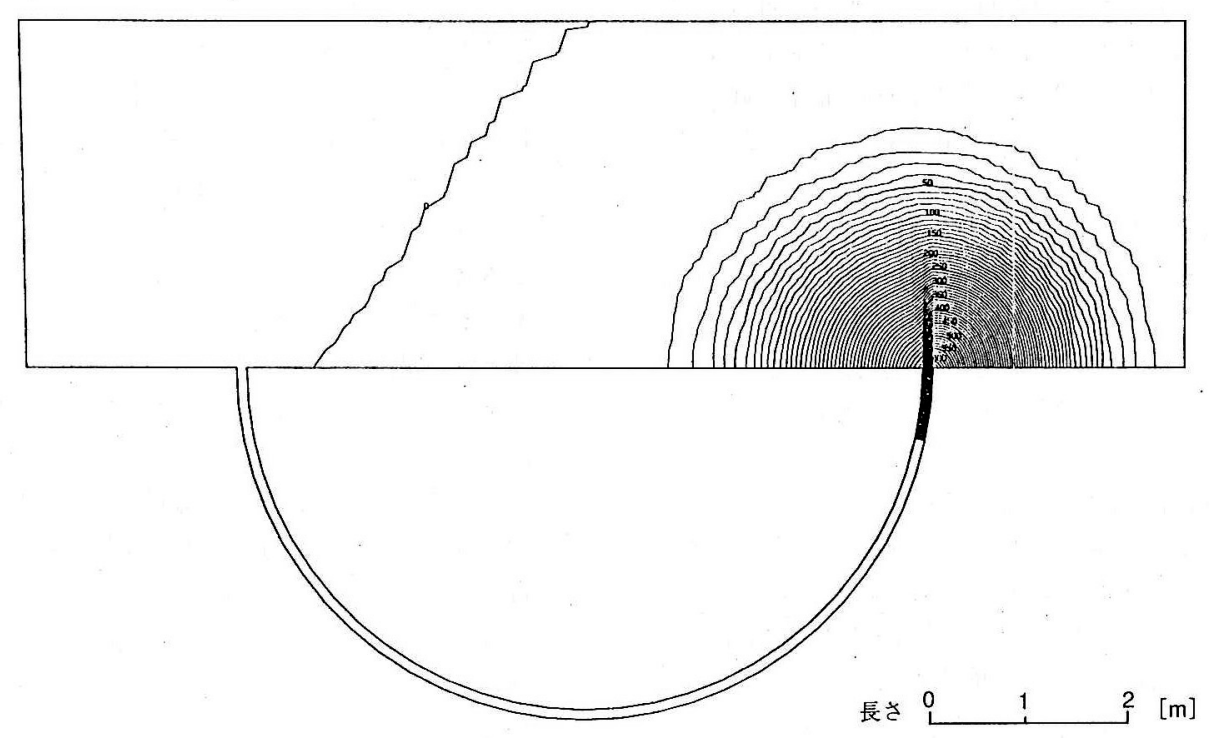

図一12 トレーサ注入後 2 時間後の浱度分布、拡大図 $(\alpha=3.5 \mathrm{~m} \quad \varepsilon=7 \%$ 、単位は ppm) 


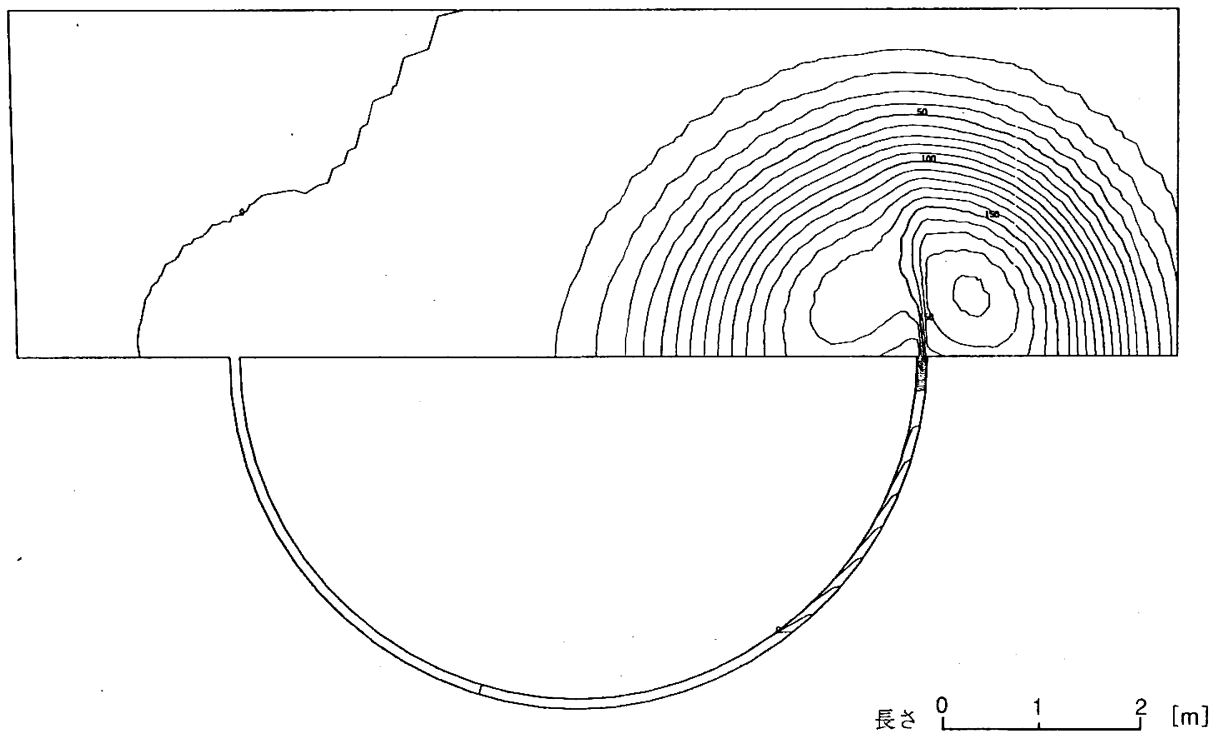

図一13 トレーサ注入後 4 時間後の檂度分布、拡大図 $(\alpha=3.5 \mathrm{~m} \quad \varepsilon=7 \%$ 、単位は ppm)

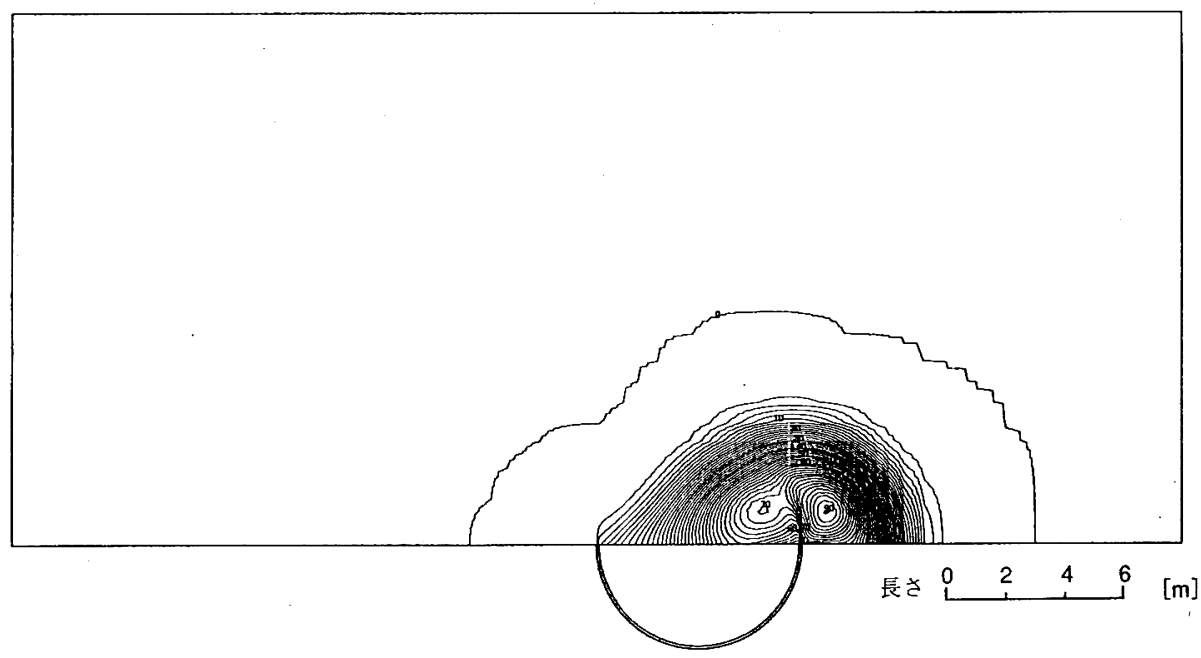

図ー14 トレーサ注入後12時間後の濃度分布

$(\alpha=3.5 \mathrm{~m} \quad \varepsilon=7 \%$ 、単位は ppm) 


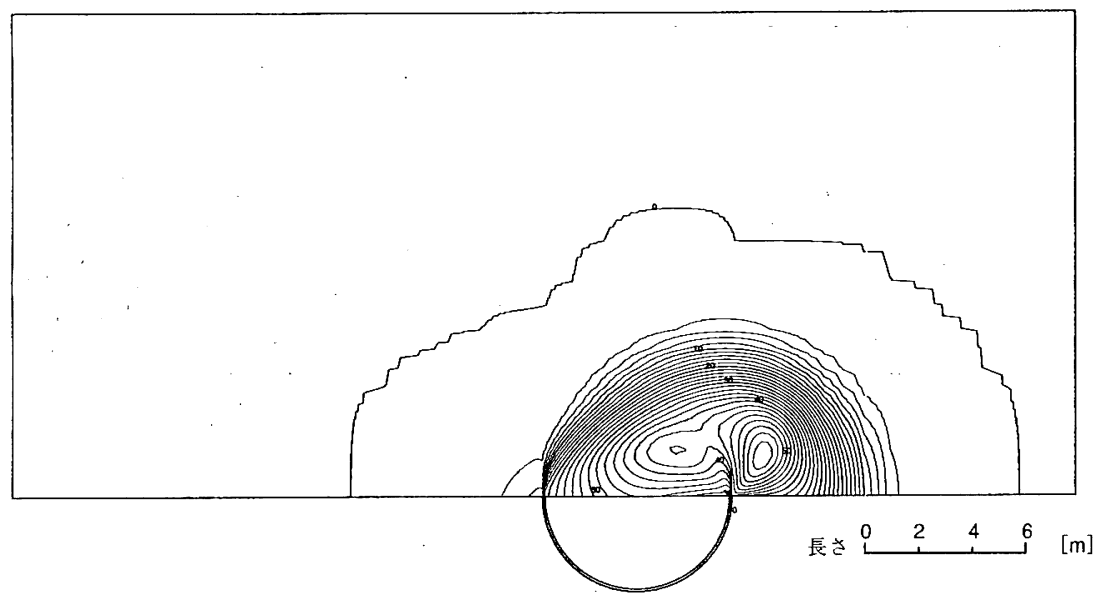

図一15 トレーサ注入後36時間後の濃度分布

$(\alpha=3.5 \mathrm{~m} \quad \varepsilon=7 \%$ 、単位は ppm)

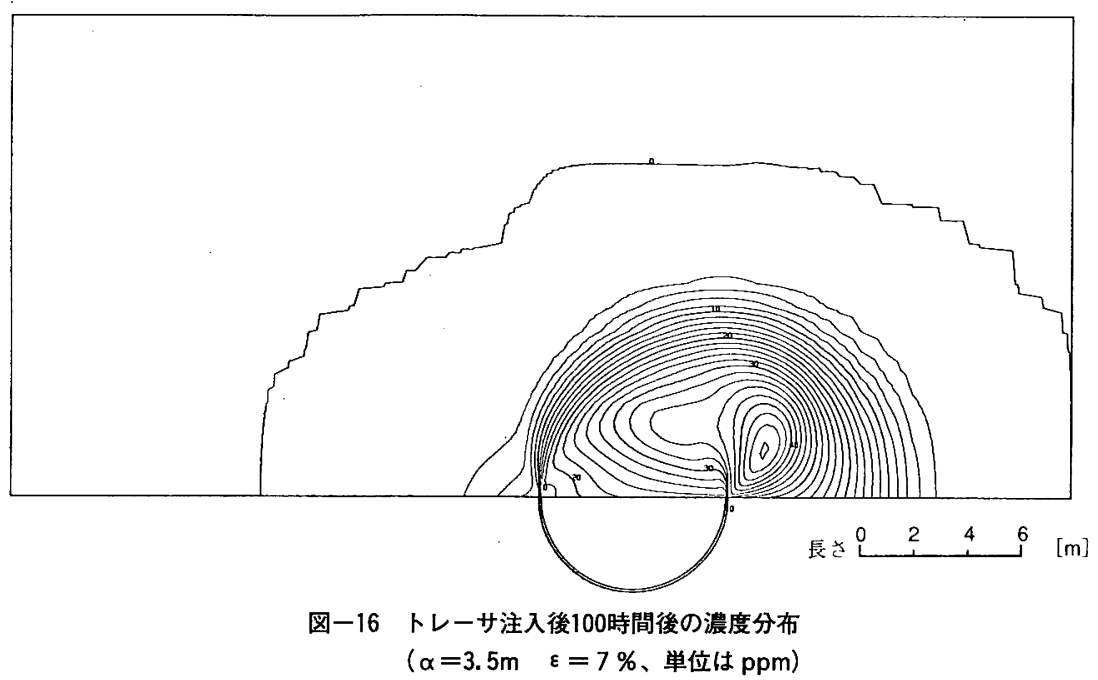

\section{考文 献}

井伊博行、堀江芳博、大场義之、杉山博道 (1990a)：ベン トナイト中での有効間隙率測定の検討、日本原子力学会、 平成 2 年年会講演要旨集、 $2 、 186$.

井伊博行、堀江芳博、大塚義之、杉山博道 (1990b)：ベン トナイトの間隙率と有効間隙率の比較、土木学会、平成 2 年年次講演会講演要旨集、 $2 、 974 \sim 975$.

石川泰、杉原弘造(1991)：インプレス：リーチング操業評 価に係わるデー夕の取得、その 1、水理特性の把握、動 燃技報、78、59 66.

櫨田吉造、田中慎一、石井卓 (1984) : 有限要素法による核 種移行問題の解法、第 6 回岩の力学国内シンポジウム、 $349 \sim 354$.
櫨田吉造 (1986) : 有限要素法による核種移行計算、日本原 子力学会、昭和61年年会講演要旨集、30.

Freeze, R. A. and Cherry, J. A. (1979): Prentice Hall, Englewood Cliffs, NJ, Groundwater, 426 430.

Leonhart, L. S., Jackson, R. L., Graham, D. L., Gelhar, L. W., Thompson, G. M., Kanehiro, B. Y. and Wilson, C. R (1985) : Analysis and Interpretation of a Recirculating Tracer Experiment Performed on a Deep Basalt Flow Top, Bulletin of the Association of Engineering Geologists, Vol. XXII, 3, 259 274.

Lynn W. Gelhar (1982) : Analysis of Two-well Tracer Tests with a Pulse Input, RHO-BW-CR-131P.

(受付 : 1991年 9 月 17 日、受理：1993年 2 月 25 日) 